\title{
ベンゾ $[a]$ ピレンのカーボンブラックへの吸着について
}

Adsorption of benzo [a] pyrene by carbon black

\author{
九州大学医学部公䍃衛生学講座 \\ 吉 柳 節 夫・倉 恒 匡 德
}

Setsuo Kiryu and Masanori Kuratsune

Department of Public Health, Faculty of Medicine, Kyushu University

One of the interesting characteristics of soots from the point of view of environmental carcinogenesis is strong adsorption of carcinogenic polycylic aromatic hydrocarbons by soots. It has been reported that soots of smaller particle size have stronger adsorptive property and this is a possible explanation for the low carcinogenic potency pertaining to those smaller soots.

The present study was undertaken in order to surface-chemically examine the adsorption of benzo $[a]$ pyrene by carbon black because such study has scarcely been reported. A commercial brand of thermal black and two brands of furnace black were examined. A known amount of a carbon black was thoroughly shaken with a measured volume of various concentrations of cyclohexane solution of benzo $[a]$ pyrene in a tube at $25^{\circ}$ or $40^{\circ}$. The resultant equilibrium concentration was estimated spectrophotometrically obtaining adsorption isotherms of the carbon black and cyclohexane system.

The results obtained were as follows:

1) Adsorption isotherms fitted the Freundlich equation except at very low concentrations.

2) Differential heat of adsorption calculated from the isotherms was 5-6 kcal/mol.

3) Neither hysteresis loop nor irreversible adsorption was recognized.

It was concluded therefore that adsorption of benzo $[a]$ pyrene by corbon black was essentially physical and not so strong as chemisorption.

\section{大気污染と肺ガンの問題に関して, ススおよびその表} 面に吸着されている発ガン物質については, 従来多くの 化学分析や動物実験が行なわれており, その間, いくつ かの興味ある事実が見出されている。たとえば Falk ら によれば, 粒子の小さいススほど, それに吸着されてい

る Benzo $[a]$ pyrene (以下 $\mathrm{Bp}$ ) を抽出し難く, このこ とが, 吸着量が大であるにもかかわらず小粒子のススの 発ガン性が低く現われる事の原因であるうと推定してい $3^{7,8)}$ 。

カーボンブラックに対する吸着の研究は, 従来極めて 多くの物質について行なわれ, 芳香族炭化水素について む, 気相や液相よりの吸着実験が界面化学的な立場から 行なわれている。しかし，それらは比較的小さい分子で あるベンゼン, ナフタリン, フントラセン等 ${ }^{4 \sim 6)} に$ 限ら れ, Bp で代表される発ガン性炭化水素程度の大きさの ものについての研究は報告されていない。

ススの中の Bp が発ガン作用を発揮するには, 生体内 でススから溶離することが必要であるから, 吸着状態は
発ガン性を左右する重要な因子である。又より小さな炭 化水素に比して Bp が異なる吸着特徴をもつか否かとい うことは興味ある問題である。このような観点から Bp の吸着について若干の基礎的な実験を試みた。

$$
\text { 実. 験 }
$$

試 料:

1. カーボンブラック
$\mathrm{A}$ ：熱分解ブラック
$\mathrm{B}$ ：フォーネスブラック $\mathrm{GPF}$
$\mathrm{C} ：$ フォーネスブラック ISAF

ヨウ素着着法3)より求めた比表面積は, A 7.6, B 16.3, C $76.0 \mathrm{~m}^{2} / \mathrm{g}$ であった。

2. ベンゾ $[a]$ ピレン, フントラセンは, ベンゼン一 メタノールより再結晶。

3. シクロへキサン, ベンゼンは蒸溜により精製。

吸 着:

$\mathrm{L}$ 字型試験管にカーボンブラック約 $0.1 \mathrm{~g}$ を精秤し, 
種々の濃度の $\mathrm{Bp}$ シクロヘキサン溶液 $10 \mathrm{ml}$ を添加し, 密栓して恒温槽中で所定の温度で 1 時間振盪して吸着平 衡に達せしめた後, 溶液を汇取, 分光々度計により平衡 濃度を測定し, さらに最初の添加量との差から, 吸着さ れた Bp 量を算出した。

\section{脱 着:}

共栓つき遠沈管中, カーボソブラック約 $0.1 \mathrm{~g}$, 溶液 $7 \mathrm{~m} l$ を用い, 上記に準じて吸着平衡に達せしめた後, 遠心分離し, 溶液 $5 \mathrm{~m} l$ をとり, 定量, 吸着量を算出す る。次いで溶媒を $5 \mathrm{~m} l$ 加元, 所定の温度で 1 時間振湯し て抽出を行ない，遠心分離後その $5 \mathrm{~m} l$ をとり定量をお こなう。以下, 各回 $5 \mathrm{ml}$ の溶媒を用いて抽出を反復し, 抽出量を求めた。

結果と考察

Bp のススへの吸着力の強いととは，しばしば経験す るところであり, Falk らの小粒子ほど Bp が溶出し難 いという報告も，小粒子ほど同一重量当りで大きな表面 積を持つことを考虑すれば， Bp 分子とカーボンブラッ ク表面に化学結合に近い強い引力があると仮定すれば容 易に解釈できる。

一般に化学吸着は単分子層で形成されるから，吸着等 温線はラングミュア式に従うことが多いと云われている が1,2)，ベンゼン，ナフタレン, アントラセン等の種々の 溶液からのカーボンブラックへの吸着は, 吸着熱の小さ いこと，脱着の容易なこと等から，物理吸着であるとさ れ，その吸着等温線はフロイントリッヒ式によく適合す るとされている4)。

Bp のカーボンブラック A， B， C への吸着等温線は Fig. 1，2 の如くであった。

フロイントリッヒ式への適合を見るために，両軸を対 数目盛にプロットすると, Fig. 3 の如く，かなりよく直 線にのるが, カーボンブラック $\mathrm{B}, \mathrm{C}$ では低濃度でやや はずれる傾向が見られた。またラングミュア式へはいず れも低濃度でしか適合しなかった。

Fig. 1 の吸着量を, ヨウ素吸着量より求めた比表面 積を用いて, 単位表面積当りに換算すると Fig. 4 の如 くになるが,この図からは表面積当りの吸着量には著し い差はないように思われる。

吸着の強さに関連する量として吸着熱の大小があり, 一般に物理吸着では $10 \mathrm{kcal} / \mathrm{mol}$ 以下であるといわれて いる1)。同一吸着量に対応する温度各 $T_{1}, T_{2}{ }^{\circ} \mathrm{K}$ での 平衡濃度 $C_{1}, C_{2}$ から算出される微分吸着熱 $Q$ は次式 より算出される。

$$
Q=4.576\left(\log p_{2}-\log p_{1}\right) /\left(1 / T_{1}-1 / T_{2}\right)
$$

Fig. 2 において, 約半飽和吸着量に対応する $25^{\circ}, 40^{\circ}$ の平衡濃度より $\mathrm{A}, \mathrm{B}, \mathrm{C}$ おのおの $5,6,6 \mathrm{kcal} / \mathrm{mol}$ が 得られ，この吸着が物理的であることがうかがわれる。

Fig. 1. Adsorption isotherms of benzo $[a]$ pyrene in cylohexane on carbon blacks at $25^{\circ}$. a, b, c: Carbon black A, B, C.
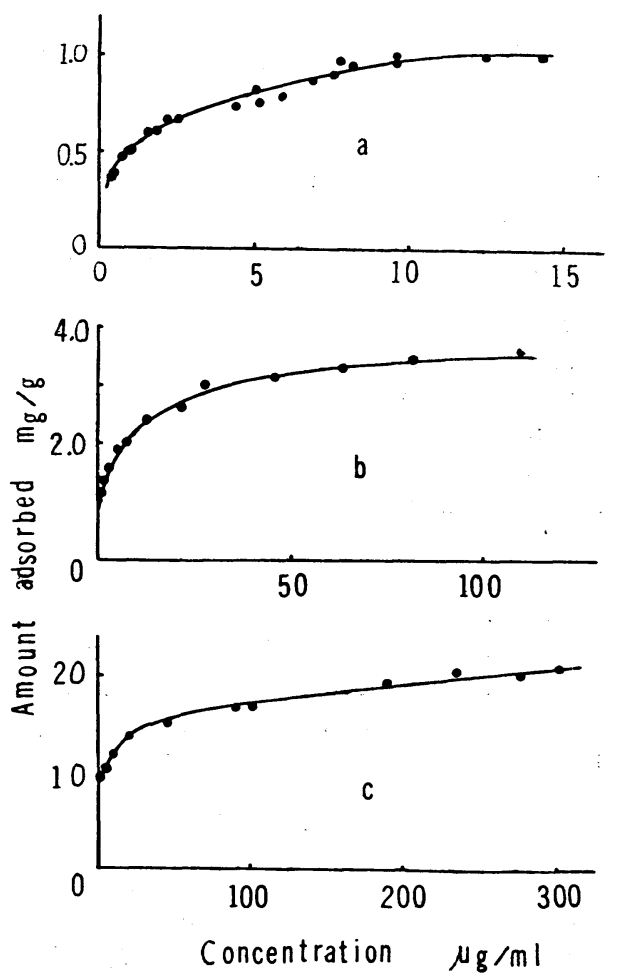

Fig. 2. Adsorption isotherms of benzo $[a]$ pyrene in cyclohexane on carbon blacks at 25 and $40^{\circ}$.

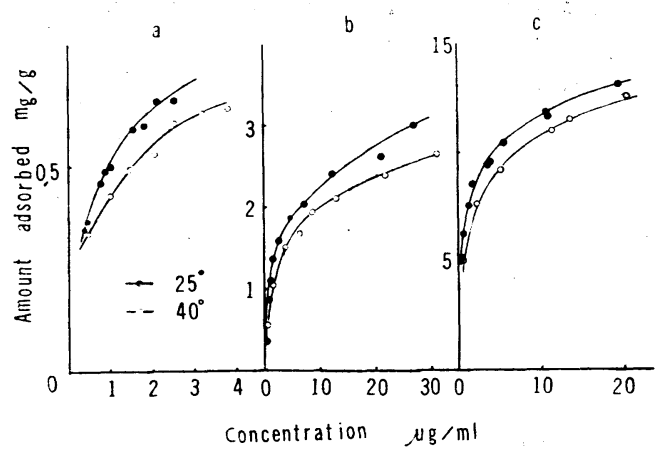


Fig. 3. Adsorption isotherms plotted according to the Freundlich equation.

d: isotherm of anthracene on carbon black $C$.

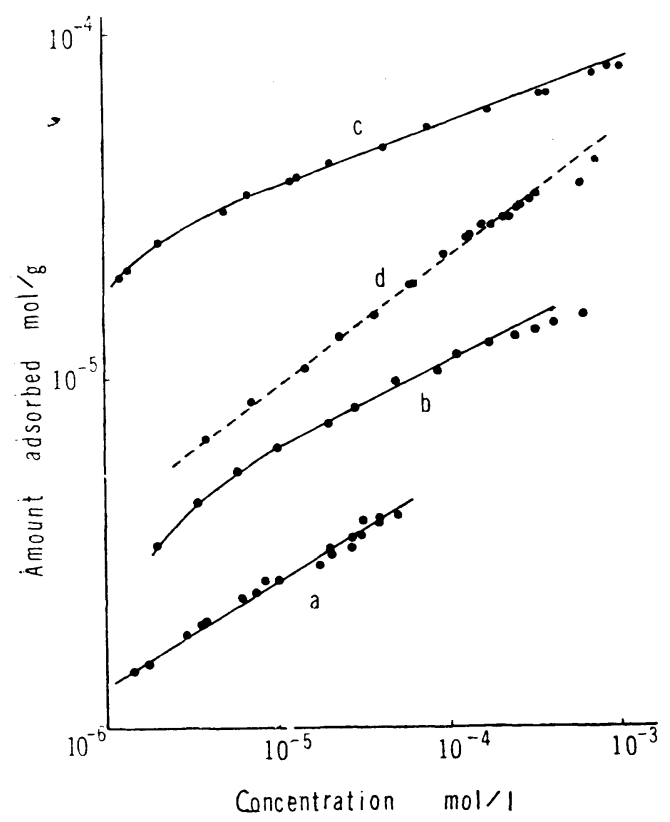

Fig. 4. Adsorption isotherms per unit surface area.

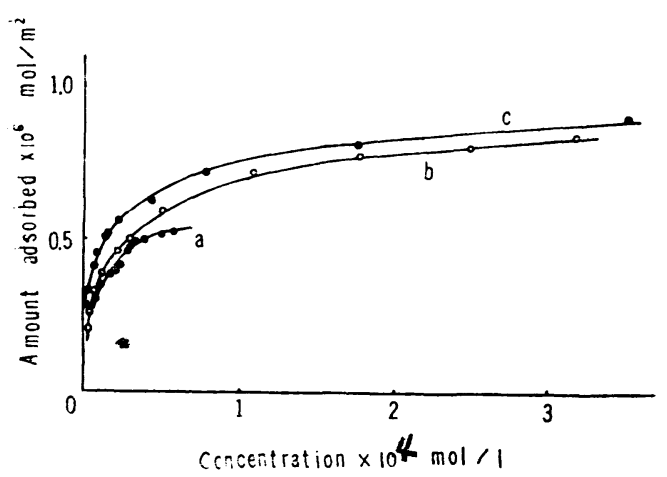

カーボンブラックに対するヨウ素の吸着では, 一部不 可逆的な強い吸着が存在することがあるといわれてい る9)。また吸着媒表面で毛管凝縮が起こる場合等では, 吸着を行なわせてつくった吸着曲線と, 一度吸着を行な わせた後, 溶液を薄め, 脱着を行なわせて平衡に達せし めた曲線とは一致しないことがあり, 履歴現象, ヒステ レシスといわれる。Bp の吸着においては, 実験の濃度 範囲でヒステレシスは認められなかった (Fig. 5)。

以上の事実から Bp の吸着がより小さい分子の吸着に 比して特異的に強い, または不可逆的なものとは考えら
Fig. 5. Adsorption isothermon on carbon black B. White circles were obtained by desorption process in which twice amount of pure cyclohexane was added to each system at equilibrium.

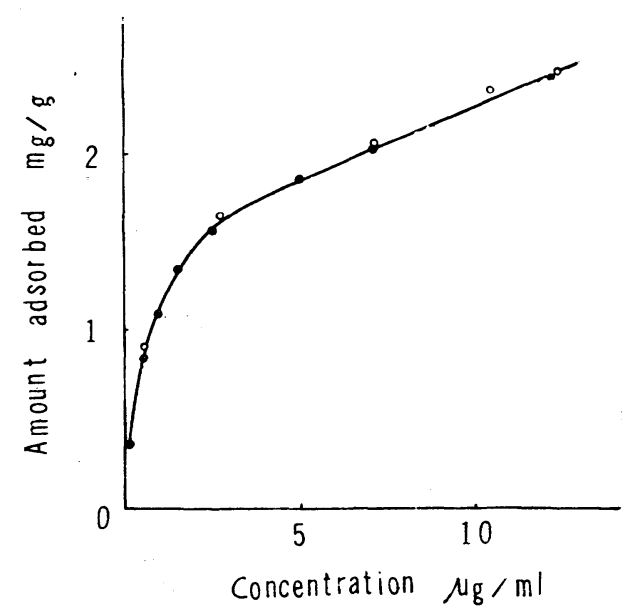

Fig. 6. Elution of benzo $[a]$ pyrene from carbon black $\mathrm{C}$ by cyclohexane $(a)$ and benzen $(b, c)$. $0.1 \mathrm{~g}$ of black was extracted by every $5 \mathrm{ml}$ of solvont.

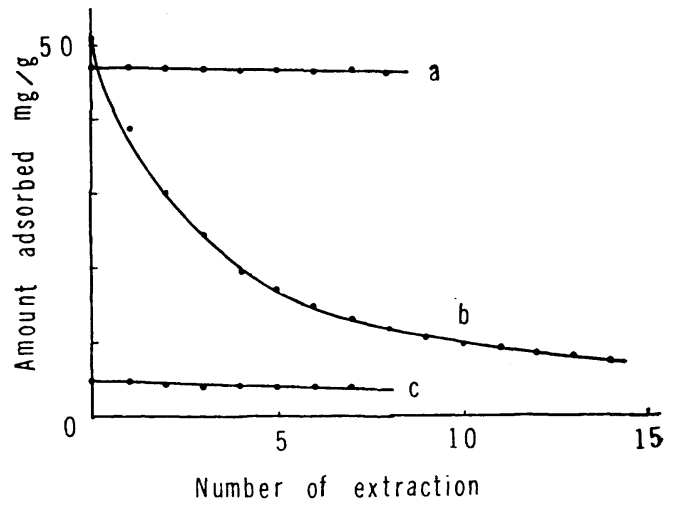

れない。しかし, 吸着曲線から示されるように, 低濃度 では平衡は著しくカーボンブラックの方に寄るので, $\mathrm{Bp}$ が微量の場合では実際上抽出されないとも云える。 シクロヘキサン $5 \mathrm{ml}$ でカーボンブラック $0.1 \mathrm{~g}$ の抽出 をくり返した脱着実験（Fig. 6, a) では抽出は殆えど行 なわれていない。

しかし, この吸着は不可逆的なものではなく,より良 溶媒であるベンゼンを用いると脱着が起こるが (b), や がて同様な状態が生じて, 実際上抽出不可能となってく る(c)。この実験では, カーボンブラック C $1 \mathrm{~g}$ に 
Bp $0.4 \mathrm{mg}$ 吸着されている場合には, ベンゼン $50 \mathrm{~m} l$ で数回くり返し抽出しても，ほとんど抽出されないこと になる。

すなわち吸着質が微量の場合, 吸着平衡は大きくカー ボンブラック側へ寄り，抽出は困難となり，その困難さ は等温吸着線の形に依存する。

結語

1. Bp のカーボンブラックヘの吸着は，ごく低濃度 を除けばフロイントリッヒ式で近似される。

2. 吸着熱は 5 6 $\mathrm{kcal} / \mathrm{mol}$ であった。

3. ヒステレシス, または不可逆的な吸着は認められ なかった。

以上から，Bp のカーボンブラックへの吸着は物理吸 着であり, 既に知られているベンゼン, ナフタレン等の 吸着に比して特に相違は認められなかった。しかしこの ような吸着でも, 吸着質が微量であれば, 実際上抽出不 可能な場合も起こり得ると思われる。
本研究は文部省科学研究特定研究「大気污染の生体に 及ほす影響」(主任研究者 北博正) の研究費によって 行なわれたものである。

\section{文献}

1) 厇田鋼蔵: 反応速度, $160 \sim 167$, 共立出版, 東京, 昭 32.

2) 庻伊富長: 吸着, $58 \sim 59$, 共立出版, 東京, 昭 40 .

3）王木国夫：日化，78，1151 4, 昭 32 .

4) 船久保英一, 他: 工化, 66, 237 41, 昭 38 .

5) van der Waarden, M.: J. Colloid Sci., 6, 4439, 1951.

6) Isirikyan, A. A. et al.: J Phys. Chem., 65, 6017, 1961.

7) Falk, H. L. et al.: Cancer Research, 12, 30-9, 1952.

8) Falk, H.L. et al.: ibid., 12, 40-3, 1952.

9) Watson, I.W. et al.: Ind. Eng. Chem., 47, 105362, 1955.

（受付 1966 年 8 月 16 日） 